\title{
Chapter 3 \\ The Rise and Demise of the Soviet-Made Housing Shortage in the Baltic Countries
}

\author{
Michael Gentile
}

\begin{abstract}
This chapter reviews the factors underlying the rapid emergence and subsequent narrowing of the Soviet-made housing shortage (i.e. the rise and slow demise of underurbanisation) in the Baltics, corroborating the analysis with findings from archival research on housing construction and allocation in the Latgalian city of Daugavpils between 1945 and 1991. It is suggested that the dynamics of the housing shortage, and the way the Soviet authorities attempted to tackle it, acted as a powerful alternative source of housing and socio-spatial differentiation, and that tracing the priorities assigned by economic planners to the different actors involved in housing construction facilitates the decoding of the Baltic residential landscapes. The chapter starts by portraying the roots of housing shortage, including the radical suppression of market forces and the housing nationalisation shock of the post-WWII years. It then discusses housing construction, housing tenure forms and housing allocation, and describes the specific experience of Daugavpils within these areas in order to shed light on the overall context of residential differentiation in the Baltics.
\end{abstract}

Keywords Housing construction - Housing allocation • Housing shortage $\cdot$ Soviet Union · Latvia • Underurbanisation

\subsection{Introduction}

Throughout the years of the Soviet occupation (1940-1941 and 1944-1991), housing was in constant short supply in the Baltics. What is defined as a shortage of housing is relative, of course. If the developing countries are used as benchmark for comparison, then the Soviet experience may be regarded as a success. If, on the other hand, the Soviet housing experience is gauged against that of the developed capitalist economies in Western Europe and North America, it clearly leaves much

M. Gentile $(\bowtie)$

Department of Sociology and Human Geography, University of Oslo, Oslo, Norway

e-mail: michael.gentile@sosgeo.uio.no

(C) The Author(s) 2019

D. B. Hess and T. Tammaru (eds.), Housing Estates in the Baltic Countries,

The Urban Book Series, https://doi.org/10.1007/978-3-030-23392-1_3 
to be desired. This chapter uses the case of the Latgalian ${ }^{1}$ city of Daugavpils to shed light on the way the Soviet housing programme slowly fought back a crisis that was largely of its own making. The main emphasis will be on Soviet housing construction and allocation practices within a context that has been characterised by 'underurbanisation', and it will be shown that both aspects were subject to the economics of prioritisation that permeated the hierarchy of industrial actors within the urban economy. The chapter starts by portraying the roots of the endemic Soviet housing shortage, including the radical suppression of market forces and the housing nationalisation shock of the post-WWII years (earlier elsewhere in the Soviet Union). It then discusses housing construction, housing tenure forms and housing allocation, and proceeds by elaborating on the specific experience of Daugavpils within these areas in order to shed light on the overall context of residential differentiation in the Baltics.

\subsection{Nationalisation and Market Suppression}

During the early years of the Soviet occupation of the Baltics, two main urban transformation processes took place at the same time. First, like elsewhere in the Soviet Union following the Bolshevik revolution, most housing had to be expropriated, nationalised and redistributed. In the case of housing, this usually meant that sitting owners became tenants and, unless they were able to find enough persons to share their dwelling within a short time, complete strangers were assigned floor space within the dwelling, imposing cohabitation with strangers and transforming the previous independent housing unit into a kommunalka, or communal apartment (Sawicki 1977; Gentile and Sjöberg 2013). Kommunalki were the standard housing predicament for the majority during the early decades of Soviet power, both within the Baltics and elsewhere in Soviet space (Bater 1980; Andrusz 1984; French 1995). Even with the advent of mass housing construction in the late 1950s, communal living within newly built apartments remained frequent for many years - an independent dwelling for a single household signalled privilege until sometime in the 1970s (Gentile and Sjöberg 2013).

The second main transformation had to do with post-war reconstruction. The building stock of many cities was left severely damaged by artillery and bombardment. The reconstruction effort targeted the affected areas (often city centres, industrial areas and train stations) in the immediate post-war years (Gentile and Sjöberg 2010a), focusing on the restoration of industrial production capacities; housing was not prioritised until after Nikita Khrushchëv denounced Stalin's 'excesses' during the so-called secret speech he gave before the All-Union

\footnotetext{
${ }^{1}$ Latgale is the south-eastern region of Latvia. It is known for its distinct regional and linguistic identity.
} 
Assembly of the Communist Party in 1956. By that time, the roots of what later became known as underurbanisation were already firmly in place.

\subsection{An Underurbanisation Crisis}

The Soviet housing crisis has been subject to numerous overlapping and complementary explanations. These include the poor starting point, the reduction in supply caused by the civil war and the two world wars, Stalin's preference for cost-ineffective grand architecture (also known as 'Stalin Baroque'), the general emphasis on heavy industry under central planning and, accordingly, the relative low priority assigned to housing construction. All of these aspects are more or less explicitly captured by the influential underurbanisation thesis proposed by Konrád and Szelényi (1974) during the 1970s and refined as a plastic model of urban growth under socialism by Murray and Szelényi (1984). In short, the underurbanisation model proposes that, following a communist revolution, three or four main stages of urban growth will likely take place. At an early stage, slight (or at times rather significant) deurbanisation will result from the direct or indirect application of anti-urban policies, including the violent removal of parts of the resident bourgeois population. At the next stage, most socialist polities are assumed to move either in a Maoist direction of decentralised industrialisation-leading to a situation of zero-urban growth - or in line with a strategy of rapid industrialisation partly decoupled from growth in other spheres of urbanity, leading to 'underurbanisation'. Underurbanised societies are thus characterised by a combination of plentiful industrial employment opportunities and inadequate urban infrastructures, including insufficient housing resources. This results in severe overcrowding within cities, as well as in substantial commuting (Murray and Szelényi 1984) and in diverted migration towards poorly serviced fringe settlements (Sjöberg 1992; Gentile 2004). Because the social and material deprivation caused by underurbanisation may lead to urban unrest, and in order to prevent rural population loss, most socialist polities restricted migration to cities (Matthews 1986; Sjöberg 1994; Buckley 1995). This migration control system, known as the propiska system in the Soviet Union and as the hukou system in China, was implemented to varying degrees of efficacy, yet it did not stop urban-bound migration, nor did it prevent commuting from outside of the administrative boundaries of controlled cities (Sjöberg 1992; Buckley 1995). In sum, underurbanisation implies a sustained gap between the low rate of urbanisation and the high rate of industrialisation. However, the logic of underurbanisation was unsustainable in the long run. Over time, most if not all of the economically advanced Soviet-style economies increased their prioritisation of consumption and housing. This is the stage Murray and Szelényi (1984) referred to as that of socialist intensive urbanisation, which arguably corresponds to the 1980s in the Baltics. By this time, however, a modest but very specific form of suburbanisation emerged in the surroundings of the region's major cities, as people started following newly created agricultural jobs, leaving an 
increasingly degraded urban environment behind them (Tammaru 2001). Despite this slight relief, Baltic cities left the Soviet Union with heavy baggage of urban imbalances inherited from decades of underurbanisation.

\subsection{Housing Construction}

The Soviet economy was thus characterised by an obstinate shortage of housing, the production and allocation of which generally favoured those employed within the economy's prioritised sectors, meaning heavy industry and defence. While the city administration bore the overall responsibility for housing construction, in practice this task was partly outsourced to the industrial enterprises that were present under its jurisdiction (Di Maio 1974; Lewis and Sternheimer 1979; Shomina 1992). This 'industrial' share of the urban housing burden is commonly known as the vedomstvennyi (departmental) sector in Russian, and the share of this sector in the total housing construction was substantial, particularly in heavy industrial cities, where it dominated completely (Shomina 1992; French 1995). However, the vedomstvennyi sector was not uniformly endowed with the resources needed to provide sufficient housing to its workers-for whom it was an important fringe benefit given its short supply (Gentile and Sjöberg 2010a, b). Two important aspects were central to the enterprises' ability to house their workers: (a) the enterprise formal subordination within the centrally planned system (enterprises under direct Moscow control were better-off), and (b) the priority of its productive activities (heavy industry and military-industrial activities being at the top). In practice, the production activities of Moscow-controlled enterprises belonged to the prioritised branches, meaning that enterprise subordination is a good proxy for economic priority.

The ensuing hierarchical stratification of the industrial sphere meant that some enterprises were in a better position to build housing - more of it, and sometimes of better quality and in better locations - than others (French 1995). The mechanism sustaining this is the differentiated enforcement of budget discipline, meaning that while some (low priority) enterprises were subject to strict budgets and penalties for non-compliance, other (prioritised) enterprises enjoyed elastic budgets allowing them to overspend without having to fear the consequences (Gentile and Sjöberg 2006, 2010b). This is the main principle of the so-called soft budget constraint, which lies at the core of Janos Kornai's economics of shortage approach to understanding central planning (see Kornai 1992).

Concordantly, housing construction under Soviet times resulted in uneven geographies of housing provision - in inequalities in location quality, neighbourhood infrastructure (including the quality and degree of completion of housing estates), and in the maintenance of the dwellings themselves. Such inequalities were produced and sustained by the cumulative effect of the housing shortage and of the diverse economic priorities enjoyed by the range of actors involved in housing construction at different points in time. The resulting pattern was an urban 
landscape of priorities, i.e. a spatio-temporal projection of priorities onto the urban landscape. At the macro-level, these priorities favoured some cities at the expense of others (Sjöberg 1999), whereas at the micro-level, they favoured certain neighbourhoods (Gentile and Sjöberg 2006, 2010b). In short, the landscape of priority was also a landscape of housing inequalities between and within cities, the physical canvas confronting the socialist system in its improbable endeavour to create a new urban society free from the socio-spatial inequalities associated with the capitalist archenemy. One of the main obstacles preventing the achievement of this goal was the extent to which the construction of different mikrorayony (neighbourhood units) was completed. High priority industry-associated mikrorayony were typically completed more rapidly, including most of the auxiliary infrastructure, whereas the little that was built by low-priority enterprises usually was a constant work in progress, unless it was embedded within an existing mikrorayon (or a mikrorayon largely built under the auspices of an organisation that enjoyed higher priority).

\subsection{Housing Tenure}

The Soviet housing system was largely based on the idea of housing as a universal right that was to be achieved through near-universal public rental at heavily subsidised rates that did not even cover the costs of (poor) maintenance (Andrusz 1984). Rental contracts were both permanent and inheritable (Sawicki 1977), which meant that they were essentially comparable to private property, albeit subject to certain limitations that are in fact not uncommon within the private sphere of market economies (e.g. the right to sublet was heavily restricted). Typically, public rental housing was either 'owned' and managed by the city (by the local Soviets, to be precise), or by the various subjects (factories or industrial enterprises) of individual branch ministries, whose housing stock was intended to be almost exclusively for the benefit of their own workers (Di Maio 1974). ${ }^{2}$

However, the demand for public rental housing greatly exceeded its supply, which is why the Soviet authorities tolerated and at times even encouraged alternative solutions. For this reason, alongside the public rental sector, the Soviet city hosted a substantial cooperative sector and an ideologically unpalatable private sector as well (Sawicki 1977; Andrusz 1984). The 'private sector' mostly consisted of unsubsidised single-family homes built to low construction standards, and it was usually not connected to the city's utility infrastructures (Alexandrova et al. 2004). Much of this sector occupied residual land that was not needed or useable for other purposes, and in some cases it may have been present on land that was earmarked

\footnotetext{
${ }^{2}$ Industrial enterprises that managed their own housing resources were typically expected to hand over a certain share (e.g. 10\%) of all new housing construction to the city administration (Andrusz 1984, p. 174).
} 
for the future expansion of existing industrial enterprises, implying that the threat of future demolition and resettlement was constantly present (Domański 1992, 1997).

The cooperative sector differed in that a substantial investment on behalf of the resident was required (Andrusz 1984). According to some of the literature, the social class structure of the residents of the cooperative sector appears to have been skewed towards the middle strata and higher (Bater 1980; Dremaite 2014, p. 200). The cooperative sector also appears to have been a reservoir for improved housing design types (Drèmaite 2014, pp. 200-203), although other studies suggest this might not always be the case owing to the characteristics and limitations of the local construction industry (Gentile and Sjöberg 2010b; Sommer 2012).

\subsection{Housing Allocation}

Throughout the Soviet Union, housing was allocated based on established norms of housing provision. An important distinction was the one between 'living space' and 'general utilisable space', with the former referring solely to the floor space of the rooms contained in a specific dwelling unit, thus excluding the kitchen, bathroom and auxiliary spaces such as corridors or windowless storage rooms (the ratio between living space and general utilisable space is approximately 2:3 in standardised apartments). The per capita norm was established using the living space criterion, meaning that rooms in kommunalki and in private apartments were assigned equal value. The general norm was set at $9 \mathrm{~m}^{2}$ as early as in 1922 (Sosnovy 1959; Sawicki 1977). At the time, this was a very ambitious target: by the time of Khrushchëv's 'secret' speech in 1956, the mean living space per capita was below $4 \mathrm{~m}^{2}$ in many of the USSR's major cities, meaning that things got worse, not better, during the years of forced industrialisation (i.e. forced underurbanisation) under Joseph Stalin.

Because housing was in short supply, and heavily subsidised, demand greatly exceeded supply. As a result, price rationing was replaced by waiting lists and administrative decision-making (Frolic 1972; Morton 1980). Because actual need was the core guiding principle in allocation, citizens were admitted into the waiting list(s) based on the characteristics of their current housing situation; in practice, this meant that only those who had less than a certain amount of living space (irrespective of whether it was located in a private apartment or in a kommunalka) were given the opportunity to join the waiting list. In most cities, the lower limit was close to $5 \mathrm{~m}^{2}$ of living space per capita, ${ }^{3}$ with variations depending on local context: for example, in Leningrad — known as the kommunalka capital of the USSR the limit was set at a mere $4.5 \mathrm{~m}^{2}$ during the late 1960s (Di Maio 1974, p. 119). In Daugavpils, the limit was set at $5 \mathrm{~m}^{2}$, but for cooperatives, it rose to 7 .

\footnotetext{
${ }^{3}$ According to Morton (1980, p. 240) this figure could have been as low as $3 \mathrm{~m}^{2}$.
} 
Once admitted into the waiting list, the house hunt was stalled for years. Exactly for how long depended on, among other things, the particular waiting list that one was admitted to. The main waiting list was the so-called general list (obshchaya ochered'), but there were also particular lists for 'young specialists', for different types of special merit, for cooperative apartments, for people with particular health problems, for people living in absolutely terrible conditions, and so forth. Some of these waiting lists moved faster than others, with the general list typically moving the slowest. The ministerial subjects had their own lists, controlled by the labour union, but all allocation decisions were approved at meetings held by the city executive committee (Di Maio 1974; see Gentile and Sjöberg 2013). Accordingly, this means that considerations relating to social merit were embedded in the housing allocation process by means of differentially functioning waiting lists (Morton 1984, p. 77). Moreover, the degree of one's association to heavy industry or defence influenced the number of dwellings - as well as their physical and locational qualities - that were within one's reach (Szelényi 1983). On top of that, there is agreement in the literature that informal and illegal practices mattered as well, although the extent of these practices is not very well known as their very nature makes them largely undocumentable beyond the anecdotal level (Matthews 1978; Domański 1997; Morton 1984; Alexeev 1988; Gentile and Sjöberg 2013). Illegality in housing allocation could take various paths: in the form of bribes or favours, through side payments upon the exchange of apartments, and through the exercise of power and influence by party officials and/or high-level representatives of prioritised industries or organisations (see Gentile and Sjöberg 2013). Taken together, all these aspects imply that Soviet housing allocation contained several steps that could have potentially contributed to social and, above all, socio-professional residential segregation. In the case of the Baltics, Moldova, the Caucasian and the Central Asian Republics, the strong connection between ethnic background and employment (and thus housing) resulted in distinct patterns of ethnic segregation (Mežs et al. 1994; Kulu 2003). However, the general lack of detailed data on segregation patterns under socialism means that we must rely on case studies using large territorial units to describe very broad (and moderate) patterns of segregation (for an overview, see French 1995). Alternatively, it is possible to infer past segregation patterns based on patterns that existed during the 1990s and 2000s, assuming low residential mobility.

\subsection{Housing Construction in Soviet Daugavpils}

This section describes the housing situation in Daugavpils (current pop. $\approx 85,000$ ), Latvia's second city, as a basis for an overall assessment of the Soviet housing system in the Baltics and in the Soviet Union. Like most cities in the Baltics, Daugavpils' population has been contracting since 1992, when it peaked at approximately 128,000 , but its current population of less than 85,000 reflects the city's particularly acute and prolonged economic and demographic decline. During 
the Soviet occupation, Daugavpils had a mixed economic base, with a handful of large industrial enterprises (the Chemical Fibre Plant or ZKhV, the Elektroinstrument tool factory, the Lokomotiv train locomotive repair works, and the Motovelotsep driving chains factory) and a number of small- or mid-sized factories within mainly construction, light manufacturing and food processing. In addition, it hosted several important military installations, including a secret airbase just outside the city. Many of these functions were located within the early nineteenth century Dinaburg fortress, which was a large closed-off (under Soviet times) territory in close proximity to the city centre. All of these actors were involved in the provision of housing to some extent, but not all were able to make substantial contributions because of the diverse budgetary circumstances that surrounded their activities (Gentile and Sjöberg 2010b).

While Daugavpils' experience, like that of any other city, is heavily contextual, the way the city developed its housing sphere sheds light on most of the aspects covered by the literature discussed above. The case study will start by using Daugavpils to illustrate the underurbanisation thesis (Murray and Szelényi 1984), followed by an analysis of the overall spatio-temporal trends in housing construction in the city. From here, the discussion will move to the outcome of the allocation process at different points in time, synthesising some of the major findings presented in Gentile and Sjöberg (2013).

At the core of the underurbanisation thesis is the observation that the rate of industrialisation under socialism - particularly during the earlier decades-proceeded faster than the rate of urbanisation (Konrád and Szelényi 1974; Murray and Szelényi 1984). Figure 3.1 illustrates how the gap between industrial employment and the cumulative Soviet-built housing supply expanded and later receded in Daugavpils. After a short stage of deurbanisation (which included deportations to Siberia), and until the mid-1950s, there was hardly any new housing construction at all, and efforts were made to restore the city's damaged production capacity. From the mid-1950s and until the mid-1960s, the city experiences a period of rapid industrial growth. While Khrushchëv's mass housing programme started more or less at the same time, it was not able to keep up with the breakneck speed of industrial employment growth, causing underurbanisation and an acute housing shortage. Employment in industry reached a stable level (whereas it continued expanding within the tertiary sector) around 1965, at which point the housing sector slowly started catching up, even though it was not until the 1980s that intensive socialist urbanisation would take place. Even so, by the time of the demise of Soviet power in 1991, Daugavpils remained the most overcrowded city in the Latvian SSR with a mere $16.8 \mathrm{~m}^{2}$ of total floor space per capita in 1990; by contrast, in Riga and Liepāja, respectively, Latvia's capital and third city, the corresponding figures were of 18.1 and $20.3 \mathrm{~m}^{2}$ (Centrālā Statistikas Pārvalde 2017). This clearly changed upon the country's re-independence, as emigration and natural population decline reduced Daugavpils' population by more than a third, rapidly turning an underurbanisation-related housing crisis into an urban shrinkage crisis of notable magnitude. 


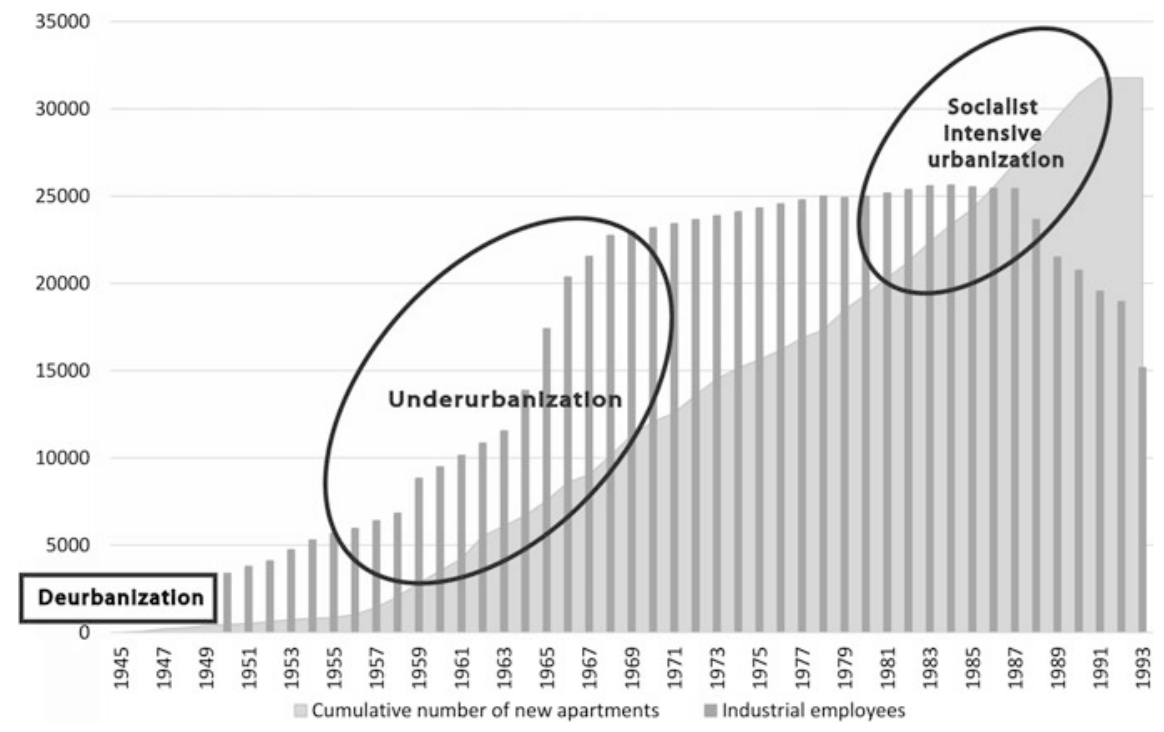

Fig. 3.1 Cumulative number of apartments built in Daugavpils (1945-1993) and number of industrial employees (1950-1993). Source Employee statistics were collected from the following documents retrieved from the Latvian National Archives (LNA), regional section in Daugavpils: LNA 26: 1: 41, LNA 39: 1: 41, LNA 136: 1: 41, LNA 83: 1: 41, LNA 136:1: 41, LNA 136: 1: 41, LNA 150:1:41, p. 85, LNA 157: 1: 41, p. 46, LNA 190: 1: 41, p. 44, LNA 199: 1: 41, p. 33, LNA 206: 1: 41, p. 11, LNA 218: 1: 41, p. 30, LNA 21: 1: 56, p. 1, LNA 37: 1: 56, p. 2, LNA 58: 1: 56, p. 2, LNA 265: 1: 41, p. 3, LNA 170: 1: 56, LNA 241: 1: 56; LNA 285:1: 56, LNA 37: 4: 56, LNA 93: 4: 56, LNA 146: 4: 56, LNA 323: 4: 56, LNA 421: 4: 56, LNA 531: 4: 56, p. 58, LNA 626: 4: 56, pp. 13-14, LNA 703: 4: 56, pp. 61-62, LNA 798: 4: 56, pp. 40-41, LNA 56: 1: 943 , pp. 8-9, LNA 56: 4: 1010, pp. 9-10, LNA 56: 4: 1127, pp. 10-11, LNA 56: 4: 1207, pp. 21-22, LNA 56: 4: 1327, pp. 13-14, LNA 56: 4: 1388, pp. 15-16, LNA 56: 4: 1481, pp. 95-96, LNA 56: 4: 1497, pp. 69-71, LNA 56: 4: 1584, LNA 36: 4: 1615, p. 47, LNA 56: 1a: 23, p. 7. Apartment data are available in Gentile and Sjöberg (2010a)

Until 1956, housing construction in Daugavpils was virtually nil. The impact of Khrushchëv's secret speech, in which he denounced Stalinism, is clearly visible in the number of apartments built starting from 1957 and onwards (Fig. 3.2).

During the period of Soviet occupation, approximately $43 \%$ of all new apartments were built on behalf of the organisation that was formally mainly responsible for this task, i.e. the city administration. However, the degree of the latter's participation in housing construction varied over time. During the meagre Stalin years, ${ }^{4}$ the little that was constructed was funded through departmental sources and, especially, the military. When Khrushchëv's housing programme took off in 1957, the city administration played an important role, but its relative presence in the mass housing programme started declining rather soon, reaching a new minimum in the

\footnotetext{
${ }^{4}$ From an urban planning and architecture perspective these years lasted until 1956 although Stalin
} died in 1953 . 


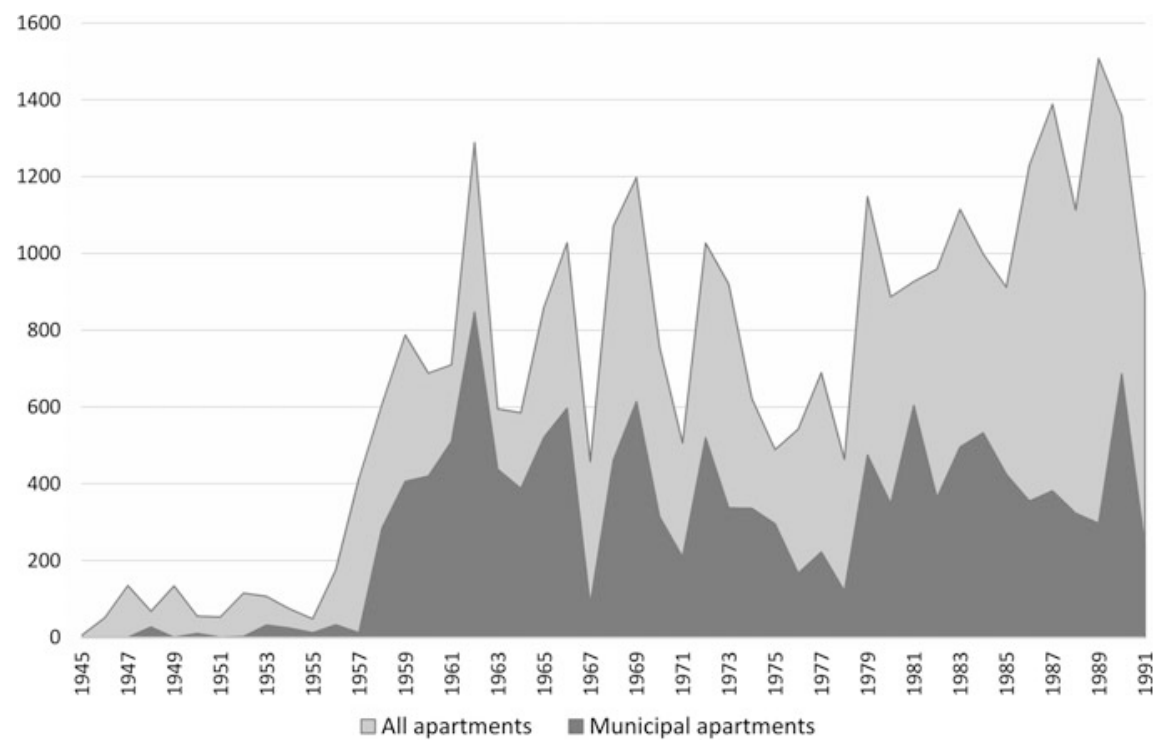

Fig. 3.2 Year-on-year construction of new apartments (number of units) in Daugavpils, in total (light) and by the city administration (dark). Source Documents retrieved from the Latvian National Archives, regional section of Daugavpils, details of sources available in Gentile and Sjöberg (2010a)

late 1970s. Between 1976 and 1979, only about a third of all completed dwellings consisted of municipal apartments, and while this share rose somewhat throughout the remaining years of Soviet power, departmental actors dominated the scene during the 1980s.

However, as discussed above, different departmental actors were endowed with different resources and budget constraints, placing them in unequal positions with respect to their ability to produce new dwellings for their workers. Figure 3.3 presents the overall employment statistics for Lokomotiv, contrasting them to the number of apartments built by the enterprise from 1950 until the end of the Soviet period. Lokomotiv was a high priority male-dominated enterprise under the direct subordination of the Moscow-level Ministry of Transport. Echoing city-wide (and Union-wide) trends, the enterprise's production of housing remained low during the Stalin years, but it increased rapidly during the years of Khrushchëv's power (1958-1964), by which time there was approximately one apartment built for every four workers. Considering that full apartments were seldom allocated to single households at the time, it is reasonable to assume that a fair share of the enterprise's workers was sheltered in enterprise-provided housing. Starting from the 1970s, however, the ratio between number of workers and (cumulative) enterprise-built housing started increasing again, particularly from the 1980s onwards, and by 1991, it had reached almost two-thirds. However, this does not mean that two-thirds of the enterprise dwellings were occupied by its workers: first of all, many of them will 


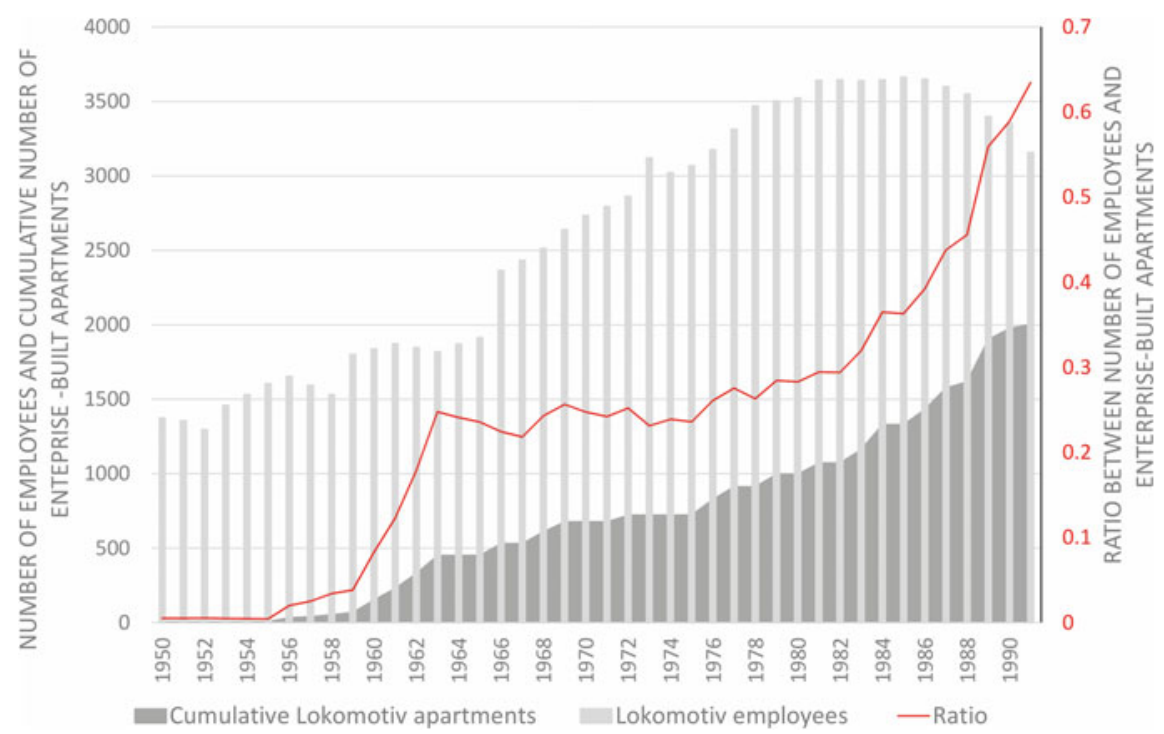

Fig. 3.3 Cumulative number of apartments built by Lokomotiv (1950-1991) and year-on-year number of employees. Sources For the employee data, see Fig. 3.1. The sources for the apartment data are available in Gentile and Sjöberg (2010b)

have retired by then, and second, eviction was only possible upon termination of employment under certain (restrictive) circumstances, meaning that the connection between employment and enterprise housing residence was flexible and incomplete (Sawicki 1977, pp. 112-113). All told, this indicates that the share of non-workers residing in Lokomotiv housing must have risen over time.

The housing story of the Chemical Fibre Plant (Zavod Khimicheskogo Volokna or $\mathrm{ZKhV}$ ) and of its mainly female workers is somewhat different. First of all, the enterprise's own subordination fluctuated between Moscow (Union-level) and joint Moscow-Riga control (Union-Republic level), signalling its relatively weaker status in the priority hierarchy. Second, unlike Lokomotiv, which expanded gradually throughout the Soviet period, ZKhV was quickly assembled starting from 1963, and it counted almost 7000 employees just a few years later. However, it reached its maximum workforce size already in 1968 and started shrinking immediately thereafter; even so, it remained the city's largest employer until the early 1990s.

Figure 3.4 compares ZKhV's workforce size and cumulative apartment output from 1963 until 1991. Unlike Lokomotiv, ZKhV started off with a 'big bang' in terms of employment, yet very little housing was constructed by the enterprise for its own workers until the late 1960s, indicating that its workers were expected to seek shelter through other channels, including the city administration's general waiting list. Moreover, certain features of $\mathrm{ZKhV}$ suggest that the plant was at least partly supposed to offset the sex-based imbalance caused by the prevalence of 'male' workplaces in Daugavpils. The implicit assumption was that the female 


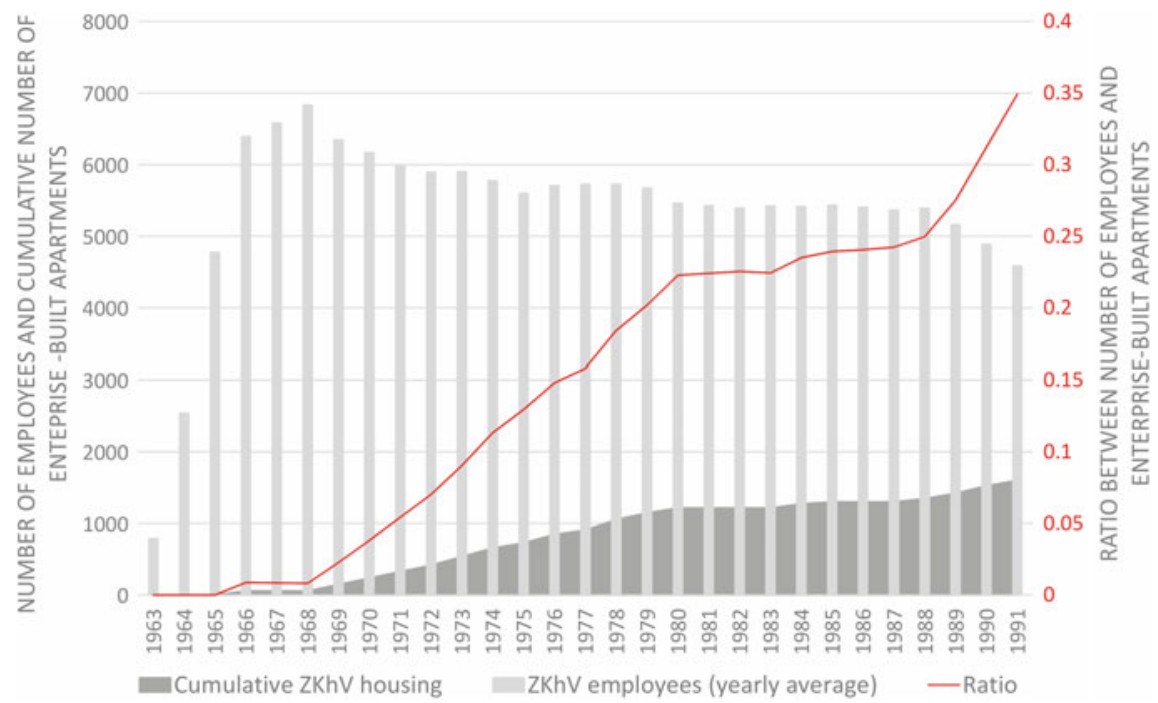

Fig. 3.4 Cumulative number of apartments built by Zavod Khimicheskogo Volokna (1963-1991) and year-on-year number of employees. Source For the employee data, the figures were retrieved from the Latvian National Archive (LNA), Daugavpils regional section, LNA 206: 1: 41, p. 11, LNA 218: 1: 41, p. 30, LNA 21: 1: 56, p. 1, LNA 37: 1: 56, p. 2, LNA 58: 1: 56, p. 2, LNA 265: 1: 41, p. 3, LNA 170: 1: 56, LNA 241: 1: 56; LNA 285:1: 56, LNA 37: 4: 56, LNA 93: 4: 56, LNA 146: 4: 56, LNA 323: 4: 56, LNA 421: 4: 56, LNA 531: 4: 56, p. 58, LNA 626: 4: 56, pp. 13-14, LNA 703: 4: 56, pp. 61-62, LNA 798: 4: 56, pp. 40-41, LNA 56: 1: 943, pp. 8-9, LNA 56: 4: 1010, pp. 9-10, LNA 56: 4: 1127, pp. 10-11, LNA 56: 4: 1207, pp. 21-22, LNA 56: 4: 1327, pp. 13-14, LNA 56: 4: 1388, pp. 15-16, LNA 56: 4: 1481, pp. 95-96, LNA 56: 4: 1497, pp. 6971, LNA 56: 4: 1584, LNA 36: 4: 1615, p. 47, LNA 56: 1a: 23, p. 7. The sources for the apartment data are available in Gentile and Sjöberg (2010a)

workers at $\mathrm{ZKhV}$ would have found their partners among the male employees of the prioritised enterprises that were prolific contributors to the city's housing stock. This was a well-known labour market (or rather, 'labour balancing') strategy in cities dominated by heavy industry or mining (Filtzer 1992), ${ }^{5}$ but the Daugavpils data suggest that the phenomenon was present in other contexts, too. This is because, unlike Lokomotiv, the $\mathrm{ZKhV}$ contributed very little to the overall housing stock, and despite the prolonged decrease in the enterprise's workforce since 1968, the ratio between the latter and the total number of units built by the enterprise only surpassed 0.25 in 1988 . However, this mainly had to do with the accelerated pace of workforce shrinkage experienced by $\mathrm{ZKhV}$ during the last years of Soviet power.

The different sizes of the $\mathrm{ZKhV}$ and Lokomotiv quantitative outputs were not the only housing-related inequality facing the workers of these enterprises. As Örjan

\footnotetext{
${ }^{5}$ Filtzer (1992, p. 64) also suggests that this strategy was less successful in cities dominated by heavy industry or mining because the high wages paid in these branches meant that a single (male) income was sufficient to sustain a household.
} 
Sjöberg and I have shown elsewhere (Gentile and Sjöberg 2010b), ZKhV and Lokomotiv also differed in the qualitative characteristics of the dwellings that they were able to supply. Specifically, whereas the ZKhV's apartments were mainly clustered in a peripheral neighbourhood of dubious environmental quality (Ķīmiķu ciemats or Chemical Settlement, named in honour of the enterprise), Lokomotiv was able to present apartments enjoying prime locational qualities, e.g. in the vicinity of an intended socialist 'new centre' that challenged the bourgeois ambiance of the old city centre, as well as next to the centrally located, aesthetically appealing, ideologically suspect and quadri-confessional 'Church Hill'.

While Lokomotiv and ZKhV serve as useful illustrations to decipher the Soviet urban landscape of priority in its Baltic guise, it is necessary to highlight that these two enterprises certainly do not represent opposites on the priority scale: they are just large enough to facilitate a fruitful comparison. If, instead, we were to scrutinise the housing geographies of the low-priority enterprises - for example, the meat combine or the local clothing factory-then the differences would become even clearer. The clothing factory had a maximum of almost 1400 workers on its payroll in 1968, but it produced almost no housing at all during the entire Soviet period. Importantly, it was not able to produce fully equipped mikrorayony, forcing its worker-residents (like those of numerous other low-priority entities) to live in unfinished and under-serviced mikrorayon fragments in perpetuity. Similarly, other low-priority enterprises contributed almost nothing to the city housing stock, although when they did, their apartments tended to have good locations, suggesting that they may have been earmarked for the upper strata of these enterprises' management (Gentile and Sjöberg 2010b). While it is not possible to determine exactly how large a share of the population residing in Soviet-era apartment blocks that was not able to enjoy the privilege of living in a fully equipped mikrorayon, data from the Latvian National Archive (see Gentile and Sjöberg 2010a) show that 10.7\% of all apartments built between 1945 and 1991 were constructed using the funds of low-priority enterprises, most of which arranged in mikrorayon fragments, as none of the low-priority enterprises ever succeeded in completing a full mikrorayon. Of course, this does not mean that the rest of the Soviet-built housing is organised in well-functioning mikrorayony, as the quality of the mikrorayony varies, but it does give an idea of the share of apartments that simply does not conform with the notion - any notion - of the integrated and spatially just socialist housing estate. For example, the meat combine, with approximately 1000 employees by the end of the Soviet period, worked on its own mikrorayon in the isolated neighbourhood of Križi (Fig. 3.5), but it only succeeded in completing six five-storey blocks between the early 1960s and 1991, with no auxiliary facilities whatsoever: given the housing shortage, new apartments were prioritised before anything else. Three more apartment blocks were being built in the early 1990s, but they were never completed and their empty carcasses continue scarring the local landscape. 


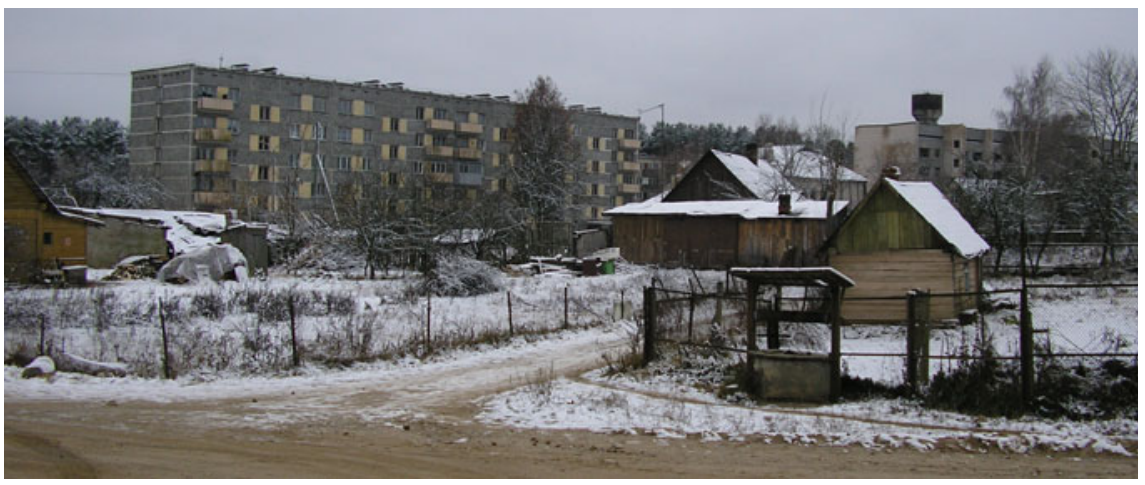

Fig. 3.5 Križi, an unfinished and isolated mikrorayon in Daugavpils. A well for the residents of the single-family housing is visible in the foreground. Source Michael Gentile

\subsection{Housing Allocation in Soviet Daugavpils}

Daugavpils suffered from a rather severe housing shortage, and although this shortage hit different socio-professional groups unequally depending on the place of employment of the person(s) in need of housing, it nevertheless influenced most of the population. Even those lucky enough to work (or have a household member working) at high priority enterprises likely had to experience one of the Soviet waiting lists. However, we know from the literature discussed earlier in this chapter that some people were more equal than others before the altar of housing allocation. This section describes the factors associated with the outcome of the allocation process in terms of assigned living space per household member, as well as the determinants of the amount of time spent waiting. The figures refer to allocation decisions that include both the assignment of (parts of) new apartments and the (re-) allocation of living space located within communal apartments.

Table 3.1 reports the mean per capita living space allocated at four different points in time, representing different stages or periods of the Soviet occupation. In terms of the Murray-Szelényi model, 1953 and 1970 denote, approximately, the beginning and endpoint of the underurbanisation stage, whereas 1980 and, especially, 1990 represent 'socialist intensive urbanisation'. The means refer to the full set of housing allocation decisions made, or in the case of departmental housing, confirmed at the gorispolkom meetings of these particular years (for 1990, owing to the high number of decisions, only the first 4 months are included); this gives a total of about 3500 decisions. All figures are reported and discussed more thoroughly in Gentile and Sjöberg (2013). The selection of indicators included in the analysis is limited by the actual information contained in the archive documents, which was not always very detailed and frequently hard to decipher. Thus, a meaningful discussion is possible in relation to gender (inferred from the applicant's name), workplace type and the applicant's type of occupation. Moreover, in most cases, it 
Table 3.1 Living space (sq. m per capita) allocated in Daugavpils in 1953, 1970, 1980 and 1990 $($ Jan-Apr). n.a $=$ not available (incomplete data)

\begin{tabular}{|c|c|c|c|c|}
\hline & 1953 & 1970 & 1980 & 1990 \\
\hline \multicolumn{5}{|l|}{$\operatorname{Sex}$} \\
\hline Male & 7.06 & 9.07 & 10.74 & 12.29 \\
\hline Female & 7.34 & 9.67 & 11.37 & 12.12 \\
\hline \multicolumn{5}{|l|}{ Surname background } \\
\hline Slavic & 7.06 & 9.35 & 11.03 & 12.17 \\
\hline Baltic & 6.07 & 9.33 & 11.07 & 12.25 \\
\hline Other & 9.01 & 8.65 & 10.78 & 11.31 \\
\hline \multicolumn{5}{|l|}{ Type of workplace } \\
\hline $\begin{array}{l}\text { Municipal and state administrative, excluding part } \\
\text { organs and law enforcement }\end{array}$ & 6.38 & 9.24 & 10.57 & 11.97 \\
\hline Non-priority industry & 6.97 & 8.36 & 10.21 & 11.77 \\
\hline Priority industry & 6.94 & 8.44 & 11.11 & 12.47 \\
\hline Law enforcement, military, political organs & 7.73 & 8.80 & 11.33 & 11.04 \\
\hline Unreported workplace & - & 10.56 & 11.97 & 12.82 \\
\hline \multicolumn{5}{|l|}{ Type of occupation } \\
\hline Unskilled & 6.29 & 8.73 & 10.42 & 11.68 \\
\hline Some skills required & 8.13 & n.a. & 10.14 & 11.96 \\
\hline Higher education required & 8.86 & n.a. & 11.37 & 11.85 \\
\hline Management & 11.62 & n.a. & 12.10 & 12.12 \\
\hline Total mean & 7.11 & 9.28 & 10.98 & 12.20 \\
\hline
\end{tabular}

Data source Gentile and Sjöberg (2013) (based on archive data assembled from multiple sources from the Latvian National Archive, Daugavpils regional section)

was possible to distinguish between people with surnames that sound 'Baltic' versus 'Slavic' (e.g. Bērzin̄š vs. Ivanov), ${ }^{6}$ allowing for the analysis of possible ethnic discrimination processes (there is a widespread belief - and also some hard evidence - in Latvia that Russians were favoured in the housing allocation process, see Mežs et al. 1994). While this is a highly imperfect proxy for ethnic background, the literature on housing markets emphasises how the ethnic associations of particular names may cause discriminatory practices (see, for example, Carpusor and Loges 2006; Andersson et al. 2012).

The first and most important trend revealed by Table 3.1 is that, over time, the amount of living space allocated increased significantly for all categories, rising from just over $7 \mathrm{~m}^{2}$ in 1953 to over 12 in 1990 . While there were some differences

\footnotetext{
${ }^{6}$ Baltic-sounding names are defined as names that suggest that the bearer is of full or partial Lithuanian, Latvian or Estonian descent. However, no Estonian-sounding surnames appeared in the studied materials. In a few cases it was not possible to establish the surname origin - either because it was unclear or because it was not legible in the document; such cases were excluded from the analysis.
} 
Table 3.2 Shares of housing beneficiaries with Baltic-sounding surnames and share of Latvians and Lithuanians in the total population of Daugavpils

\begin{tabular}{l|l|l|l|l|l}
\hline & 1953 & $1959 / 1960$ & 1970 & $1979 / 1980$ & $1989 / 1990$ \\
\hline $\begin{array}{l}\text { Share of housing beneficiaries } \\
\text { with Baltic-sounding surnames } \\
(\%)\end{array}$ & 9 & 6.2 & 16.4 & 10.5 & 14 \\
\hline $\begin{array}{l}\text { Latvian and Lithuanian share } \\
(\%) \text { of city population }\end{array}$ & 18 & 15.2 & 12.1 & 13.4 & 14.4 \\
\hline
\end{tabular}

Sources Gentile and Sjöberg (2013) (based on archive data assembled from multiple sources from the Latvian National Archive, Daugavpils regional section and Soviet census data). The $18 \%$ share of Latvians and Lithuanians in 1953 is an estimate based on the shares present during earlier and the subsequent 1959 census

between men and women (in both directions), gender clearly had little or no effect on the housing allocation decision. Having a Slavic-sounding surname, on the other hand, was associated with a better outcome in 1953-7 $\mathrm{m}^{2}$ versus only 6 for applicants with Baltic-sounding surnames: at such low levels, this a $1 \mathrm{~m}^{2}$ difference matters. ${ }^{7}$ Even so, in a multivariate setting (reported in Gentile and Sjöberg 2013), this differential appears to be explained by other factors, most notably those related to professional status. Yet the fact remains: in the years of Stalinhood, Balts were allocated smaller dwellings, and members of this group may have noticed this and drawn their own conclusions about their being discriminated against (after all, social status was not supposed to influence the allocation decisions).

As to workplace type, moderate differences in allocation outcome were present at an early stage, but they too decreased over time. Interestingly though, it was those employed within law enforcement, the military and the political organs that benefited the most. From 1970 and onwards, a category of beneficiaries emerges whose workplace happens to have been 'forgotten' in the official allocation decisions. This particular category happened to be the most successful, even in 1990. However, what appears to have mattered most is the type of occupation of the applicant, reflecting social status within Soviet society. In 1953, people in managerial occupations received almost twice the amount of living space compared to workers in unskilled occupations, and even though this gap was significantly reduced over the years of Soviet power, it remained in place in 1990.

While the findings from Table 3.1 suggest that little or no ethnic (surname) discrimination took place within the housing allocation process in Daugavpils, the matter cannot be dismissed entirely. Indeed, Table 3.2 shows that Latvian- and Lithuanian-sounding (i.e. Baltic) surnames were generally under-represented among the allocation decisions when compared to these two groups' relative shares of Daugavpils' total population, even though the opposite is true for 1970. This suggests that the process of admitting people into the waiting list favoured

\footnotetext{
${ }^{7}$ The "Other" surname background group (e.g. Georgian, German, Turkic, etc., sounding names) is too small, so its apparent advantage in 1953 is probably due to chance.
} 
outsiders, i.e. immigrants from (mainly) Russia and Belarus. Direct discrimination or purposeful Russification is thus neither confirmed nor refuted, but the outcome of the process nevertheless meant that Latvians and Lithuanians became under-represented in state-owned dwellings - especially within housing estatesand over-represented within the 'private sector', as was the case elsewhere in the Baltics (see, e.g. Hess et al. 2012).

In Table 3.3, mean waiting times in years are reported for all allocation decisions made in 1970, 1980 and 1990 (the data coverage was insufficient for 1953 and 1960). As with the allocation of living space, the trend appears to be towards both improvement and increasing fairness, yet the differences between different groups are more revealing and somewhat more resistant to time-but less so to testing in a multivariate setting [Gentile and Sjöberg (2013) do this for 1980 and 1990]. Thus, even though differences between men and women may be 'explained' by socio-occupational status, they in turn lead back to the Soviet gender-based labour market segmentation that systematically 'placed' women in lower skilled jobs (Filtzer 1992; Katz 2001). In other words, gender-based discrimination in the labour market was exacerbated by its consequences within other spheres, in this case housing allocation. A similar line of reasoning might hold in relation to the fact that

Table 3.3 Mean number of years spent waiting for new accommodation once admitted into the housing waiting list

\begin{tabular}{|c|c|c|c|}
\hline & 1970 & 1980 & 1990 \\
\hline \multicolumn{4}{|l|}{ Gender } \\
\hline Male & 5.22 & 5.43 & 4.26 \\
\hline Female & 6.22 & 5.78 & 4.52 \\
\hline \multicolumn{4}{|l|}{ Surname origin } \\
\hline Slavic & 5.43 & 5.35 & 4.33 \\
\hline Baltic & 6.25 & 5.85 & 4.60 \\
\hline Other & 4.77 & 5.57 & 4.93 \\
\hline \multicolumn{4}{|l|}{ Type of workplace } \\
\hline $\begin{array}{l}\text { Municipal and state administrative, excluding party organs and } \\
\text { law enforcement }\end{array}$ & 6.30 & 5.97 & 4.32 \\
\hline Non-priority industry & 5.58 & 6.01 & 5.08 \\
\hline Priority industry & 5.03 & 6.55 & 5.14 \\
\hline Law enforcement, military, political organs & 3.00 & 2.80 & 3.50 \\
\hline Unreported workplace & 4.25 & 3.47 & 3.38 \\
\hline \multicolumn{4}{|l|}{ Type of occupation } \\
\hline Unskilled & n.a. & 6.51 & 4.84 \\
\hline Some skills required & n.a. & 6.32 & 4.88 \\
\hline Higher education required & n.a. & 4.58 & 3.63 \\
\hline Management & n.a. & 3.03 & 4.45 \\
\hline Total mean & 5.51 & 5.57 & 4.40 \\
\hline
\end{tabular}

Source Gentile and Sjöberg (2013) (based on archive data assembled from multiple sources from the Latvian National Archive, Daugavpils regional section) 
people with Baltic surnames generally spent more time on the waiting list than their Slavic-sounding counterparts, although the gap narrowed over time. Even so, as in the case of living space allocation, the length of the waiting times appears to have been influenced by the applicant's workplace and occupation type, suggesting the presence of meritocratic principles alongside systemic 'impurities' such as bribery and the plain exertion of political 'clout' (as the shorter waiting times for the unreported workplaces would suggest). Needless to say, higher socio-occupational status and working within the 'right' spheres also gave a ticket to faster progress in the Soviet house hunt.

\subsection{Conclusion}

This chapter reviewed the factors underlying the widening and subsequent painfully slow narrowing of the Soviet housing shortage in the Baltics, corroborating the analysis with findings on housing construction and allocation in Daugavpils. While the absence of market allocation prevented the formation of socio-economic spatial differentiation patterns based on price rationing, the dynamics of the housing shortage, and the way the Soviet authorities attempted to tackle it, were a powerful alternative source of socio-spatial differentiation in their own right. Two aspects were especially important in this respect: shortages and priorities. Because cities hosted hierarchically arranged multiple branch-subordinated economic agents (enterprises enjoying different budgetary leeway), many of which actively engaged in housing construction and de facto urban planning, prioritised enterprises were in a better position to house their workers and to embrace (or seize) relatively comprehensive urban planning tasks. Put differently, such enterprises were able to produce full mikrorayony, better serviced, better located and perhaps even better built. At the other end of the priority scale, we have enterprises that were unable to play the housing card to attract workers; such enterprises were typically within light industry or the 'non-productive' sphere, and women overwhelmingly staffed them. And in between these two extremes, a wide range of actors did the best they could, resulting in a diverse urban landscape of priorities in which architectural homogeneity (based on the limitations of the local construction industry) concealed noteworthy differences in the locational and qualitative assets of housing, and where the forthright inequalities of market-based housing allocation were replaced by the oblique outcome of a need-based system maintained by demi-Kafkaesque bureaucracies. Accordingly, the Soviet housing estates-the essence of socialist standardisation and alleged socio-spatial justice - were in fact unequal on various accounts: they differed by size, by degree of completion and endowment with auxiliary functions, by locational quality (i.e. in relation to the city centre, to various urban amenities and to employment opportunities), and, to some extent, by physical quality. This situation was shared not only within the Baltic region, but also well beyond, and it represents the starting point for the introduction of market reforms. The latter, in turn, have structured the Baltic cities' socio-economic 
residential segregation patterns during the past three decades along the lines of the 'socialist' housing differentiation patterns heritage, and they will continue doing so in the foreseeable future.

\section{References}

Alexandrova A, Hamilton E, Kuznetsova P (2004) Housing and public services in a medium-sized Russian city: case study of Tomsk. Eurasian Geogr Econ 45(2):114-133

Alexeev M (1988) The effect of housing allocation on social inequality: a soviet perspective. J Comp Econ 12(2):228-234

Andersson L, Jakobsson N, Kotsadam A (2012) A field experiment of discrimination in the Norwegian housing market: gender, class, and ethnicity. Land Econ 88(2):233-240

Andrusz G (1984) Housing and urban development in the USSR. SUNY Press, New York

Bater J (1980) The soviet city. E. Arnold, London

Buckley C (1995) The myth of managed migration: migration control and market in the Soviet period. Slav Rev 54(4):896-916

Carpusor A, Loges W (2006) Rental discrimination and ethnicity in names. J Appl Soc Psychol 36 (4):934-952

Centrālā Statistikas Pārvalde (2017) Table A_MAG07. Housing stock by statistical region, city and district at the end of the year, 1990-2009, downloaded from the Centrāla Statistikas Pārvalde electronic database at http://data.csb.gov.lv/. Accessed 11 Nov 2017

Di Maio A (1974) Soviet urban housing: problems and prospects. Praeger, New York

Domański B (1992) Social control over the milltown: industrial paternalism under socialism and capitalism. Tijdschrift voor Economische en Soc Geogr 83(5):353-360

Domański B (1997) Industrial control over the socialist town: benevolence or exploitation?. Praeger, New York

Dremaite M (2014) Architecture and housing in Soviet Lithuania. DOM Publishers, Berlin

Filtzer D (1992) Soviet workers and de-stalinization - the consolidation of the modern system of soviet production relations 1953-1964. Cambridge University Press, Cambridge

French RA (1995) Plans, pragmatism and people: the legacy of Soviet planning for today's cities. UCL Press, London

Frolic BM (1972) Decision making in Soviet cities. Am Polit Sci Rev 66(1):38-52

Gentile M (2004) Former closed cities and urbanisation in the FSU: an exploration in Kazakhstan. Eur Asia Stud 56(2):263-278

Gentile M, Sjöberg Ö (2006) Intra-urban landscapes of priority: the Soviet legacy. Eur Asia Stud 58(5):701-729

Gentile M, Sjöberg Ö (2010a) Soviet housing: who built what and when? The case of Daugavpils, Latvia. J Hist Geogr 36(4):453-465

Gentile M, Sjöberg Ö (2010b) Spaces of priority: the geography of Soviet housing construction in Daugavpils, Latvia. Ann Assoc Am Geogr 100(1):112-136

Gentile M, Sjöberg Ö (2013) Housing allocation under socialism: the Soviet case revisited. Post-Sov Aff 29(2):173-195

Hess DB, Tammaru T, Leetmaa K (2012) Ethnic differences in housing in post-Soviet Tartu, Estonia. Cities 29(5):327-333

Katz K (2001) Gender, work and wages in the Soviet Union: a legacy of discrimination. Palgrave, Basingstoke and New York

Konrád G, Szelényi I (1974) Social conflicts of underurbanisation. In: Brown A, Licari J, Neuberger E (eds) Urban and social economics in market and planned economies: policy, planning, and development, vol 1. Praeger, New York, pp 206-226 
Kornai J (1992) The socialist system: the political economy of communism. Oxford University Press, Oxford

Kulu H (2003) Housing differences in the late Soviet city: the case of Tartu, Estonia. Int J Urban Regional Res 27(4):897-911

Lewis C, Sternheimer S (1979) Soviet urban management, with comparisons to the United States. Praeger, New York

Matthews M (1978) Privilege in the Soviet union: a study of elite life-styles under communism. Allen \& Unwin, London

Matthews M (1986) Poverty in the Soviet Union: the life-styles of the underprivileged in recent years. Cambridge University Press, Cambridge

Mežs I, Bunkše E, Rasa K (1994) The ethno-demographic status of the Baltic states. GeoJournal 33(1):9-25

Morton H (1980) Who gets what, when and how? Hous Sov Union Sov Stud 32(2):235-259

Morton H (1984) Housing in the Soviet Union. Proc Acad Polit Sci 35(3):69-80

Murray P, Szelényi I (1984) The city in the transition to socialism. Int J Urban Reg Res 8(1):90107

Sawicki SJ (1977) Soviet land and housing law: a historical and comparative study. Praeger, New York

Shomina E (1992) Enterprises and the urban environment in the USSR. Int J Urban Reg Res 16 (2):222-233

Sjöberg Ö (1992) Underurbanisation and the zero urban growth hypothesis: diverted migration in Albania. Geogr Ann Ser B Hum Geogr 74(1):3-19

Sjöberg Ö (1994) Rural retention in Albania: administrative restrictions on urban-bound migration. East Eur Q 28(2):205-233

Sjoberg Ö (1999) Shortage, priority and urban growth: towards a theory of urbanisation under central planning. Urban Stud 36(13):2217-2236

Sommer S (2012) Soviet housing construction in Tartu: the era of mass construction (1960-1991), Master's thesis, Department of Geography, University of Tartu, Tartu. Available for download at http://cmus.ut.ee/wp-content/uploads/2013/09/2012-magister-Sille-Sommer.pdf. Accessed 10 Nov 2017

Sosnovy T (1959) The Soviet housing situation today. Sov Stud 11(1):1-21

Szelényi I (1983) Urban inequalities under state socialism. Oxford University Press, Oxford

Tammaru T (2001) Suburban growth and suburbanisation under central planning: the case of Soviet Estonia. Urb Stud 38(8):1341-1357

Open Access This chapter is licensed under the terms of the Creative Commons Attribution 4.0 International License (http://creativecommons.org/licenses/by/4.0/), which permits use, sharing, adaptation, distribution and reproduction in any medium or format, as long as you give appropriate credit to the original author(s) and the source, provide a link to the Creative Commons license and indicate if changes were made.

The images or other third party material in this chapter are included in the chapter's Creative Commons license, unless indicated otherwise in a credit line to the material. If material is not included in the chapter's Creative Commons license and your intended use is not permitted by statutory regulation or exceeds the permitted use, you will need to obtain permission directly from the copyright holder. 